\title{
RETHINKING SERVICE RECOVERY: A CUSTOMER EMPOWERMENT (CE) PERSPECTIVE
}

\author{
Ljudevit Pranic $^{1}$, Wesley S. Roehl ${ }^{2}$ \\ ${ }^{1}$ Faculty of Economics, University of Split, Matice hrvatske 31, 21000 Split, Croatia \\ ${ }^{2}$ School of Tourism and Hospitality Management, Temple University, \\ 1810 N. $13^{\text {th }}$ Street, Speakman Hall Philadelphia, PA 19122, USA \\ E-mails: ${ }^{1}$ ljudevit.pranic@efst.hr (corresponding author); ${ }^{2}$ wroehl@temple.edu
}

Received 26 January 2011; accepted 10 June 2011

\begin{abstract}
Generally, complainants have been given little power to effect how their service recovery encounter unfolds. Meanwhile, the satisfactory resolution of customer complaints has been a challenging task for many service organizations. Empowering customers in service recovery provides a solution for this challenge. However, the studies on customer empowerment (CE) have taken very narrow perspectives of $\mathrm{CE}$ and therefore, none of them individually can explain the nature of $\mathrm{CE}$ in service recovery situations among various services that represent the services industry. Based upon the review of the previous research, this article proposes a more integrative theoretical framework in an attempt to better describe and explain the customers' view of CE in the management of service recovery encounters. According to the proposed model, the degree of complainantperceived empowerment during service recovery determines both the level of complainant's affective/cognitive responses and the level of subsequent complaint satisfaction. Implications are provided and discussed from both practical and theoretical perspectives.
\end{abstract}

Keywords: customer empowerment, complainant empowerment, customer view, service recovery, complaint satisfaction.

Reference to this paper should be made as follows: Pranic, L.; Roehl, W. S. 2012. Rethinking service recovery: a customer empowerment (CE) perspective, Journal of Business Economics and Management 13(2): 242-260.

JEL Classification: M30.

\section{Introduction}

'He who wears the shoe knows best where it pinches' (an old proverb)

It is a straightforward economic argument that the satisfactory resolution of customers' complaints in service recovery is a critical driver of customer loyalty, positive wordof-mouth, cross-buying from the firm's portfolio of offerings (Mittal et al. 2005), and subsequently, the firm's long-term financial performance (Rust et al. 2000). Yet, despite the costs and benefits associated with service recovery, many customers who encounter service failures are dissatisfied with the handling of their complaints (Tax, Brown 1998). What causes this discontent is customers' inability to control and/or influence policies 
and procedures (e.g., service recovery unfolding) directly affecting their lives (Kosciulek 1999a, 1999b). Generally, complainants have had little impact on how service providers respond to service failure. That is, those experiencing the service failure event have been given little power to effect how their service encounter unfolds. This lack of power and control suggests a greater need for complainant empowerment.

Traditionally, customer empowerment (CE) has been considered from the firm's point of view wherein delegation of activities to customers may lead to greater management efficiency, as the customer carries out tasks that otherwise have to be carried out by the company's employees (Fuchs, Schreier 2011; Hoffman, Bateson 1997). In recent years, however, management research on $\mathrm{CE}$ has witnessed a shift from the perspective of improving task efficiency (organization's view) to that of offering important yet often unattended benefits to customers (customer's view; Fuchs et al. 2010; Kosciulek 2005, 1999a, 1999b; Kosciulek, Merz 2001). This shift has been advocated by several scholars in both healthcare and new product development (NPD) research, who recognize that CE strategies can ensure happier customers thanks to a closer fit between customer preferences and product/service attributes (Franke et al. 2009; Fuchs et al. 2010; Kosciulek 2005, 1999a, 1999b). However, both research streams take a narrow perspective of CE. Therefore, none of them individually can explain the nature of CE in service recovery situations among various services that represent the services industry.

In contrast to the recent $\mathrm{CE}$ tendencies, this conceptual article extends the notion of $\mathrm{CE}$ into (1) situations beyond original/initial service and product encounters, i.e. service recovery encounters, and (2) contexts beyond the healthcare setting, i.e. other services such as hotels, restaurants, airline travel, retail banking, etc. It does so by presenting an integrative model of service recovery from the complainant's point of view that can serve as the theoretical foundation for the development and evaluation of service recovery policy and complaint satisfaction in the services industry. For the purposes of this research, we define $\mathrm{CE}$ as a strategy firms use to give complainants sufficient information and a sense of control and competence over a company's service recovery process, allowing them to self-select remedies the company will then use to correct a wrong.

Thus, our key proposition is that the degree of complainant-perceived empowerment during service recovery determines both the level of complainant's affective/cognitive responses and the level of subsequent complaint satisfaction. We argue that there is not a certain magic at work that changes the complainants' subjective evaluations of service recovery (i.e., that empowered complainants evaluate the underlying service recovery more favorably than non-empowered complainants). Instead, this theoretical prediction can be derived because empowered complainants might be emotionally and cognitively enriched by their participation in service recovery, which in turn might increase their satisfaction. We use these ideas as a starting point for our research. In what follows, we begin by conceptually exploring the complainant's view of service recovery, and then we theoretically develop and define the proposed relationships among five selected constructs (CE, affect, service quality, fairness, and complaint satisfaction) in the proposed service recovery model. 


\section{Complainant's view of service recovery}

Service recovery refers to a process-related criterion (as opposed to an outcome-based criterion; Grönroos 1988, 1984) in customers' evaluations of actions taken by an organization and its employees in response to a customer complaint following a service failure (Zeithaml, Bitner 2000).

No matter how well the service process is designed and employees trained, some degree of service failure between customer and service provider is certain (Zeithaml, Bitner 2000). Despite the inevitability of some service failure, dissatisfied customers are avoidable (Hart et al. 1990) as it is not the initial failure to deliver the expected service that causes dissatisfaction, but rather the employees' lack of appropriate response to that failure (Bitner et al. 1994). Paradoxically, customers who are dissatisfied, but experience an excellent service recovery, may ultimately be even more satisfied than before and more likely to remain loyal to the service provider (Hart et al. 1990).

When service fails, some customers choose to complain to the service provider (Ekiz, Arasli 2007). Subsequently, some service providers engage in service recovery in an attempt to rectify a customer complaint regarding a perceived service failure (Spreng et al. 1995). Service recovery thus refers to any actions taken by an organization and its employees in response to a customer complaint following a service failure (Becker 2000; Spreng et al. 1995; Zeithaml, Bitner 2000). Customer satisfaction is influenced by both cognitive (specific product or service features, customers' perceptions of quality, their attributions for service success or failure, and their perceptions of fairness) and affective (customers' emotional responses) phenomena (Liljander, Strandvik 1997; Zeithaml, Bitner 2000).

Within the context of service recovery, it seems reasonable to expect that because the complainant is more actively engaged in a service recovery act (via complaining), and has more investment in that interaction, complainant's emotions would be more significantly engaged by recovery encounters than emotions of customers in ordinary (i.e., initial, non-recovery) service encounters. Despite the important link between complainants' emotions and their satisfaction or dissatisfaction with service recovery, service providers often employ various defensive strategies (i.e., complaint management programs (i.e., Fornell, Wernerfelt 1987) and service guarantees (i.e., Hart 1988) that only seem to treat the symptoms (as opposed to treating the causes) of discontent. This is no surprise since research shows that, despite significant advances in service recovery research, little is known about complainants' emotional responses to service recoveries (Chebat, Slusarczyk 2005).

What causes this discontent is complainants' inability to control and/or influence policies and procedures (e.g., type of service recovery remedy) directly affecting their lives (Kosciulek 1999a, 1999b). This lack of control suggests a greater need for complainant empowerment. To date, evidence from business management scholarly literature and practice suggests that $\mathrm{CE}$ is seen as a construct representing the provider's point of view. According to this perspective, delegation of activities to customers may lead to greater management efficiency, as the customer carries out tasks that otherwise have to be carried out by the service provider's employees (e.g., Hoffman, Bateson 1997). 
In addition to this view, some scholars in healthcare services consider CE as a construct that also includes a customer's point of view. Here, both the technical (i.e., outcome) aspect and the customer service (i.e., process) aspect should be shaped to meet the needs and preferences of individual patients/customers (Institute of Medicine [IOM] 2001; Tressolini, The Pew-Fetzer Task Force 1994). Because patients' preferences are vastly erratic, clinicians alone cannot make the best decisions for their patients (IOM 2001). Additionally, patients increasingly require information and participation in decisionmaking (IOM 2001). Moreover, allowing patients to play the central role in service production and delivery can improve the outcomes they desire (IOM 2001) and may bring about patient satisfaction (Kosciulek 1999a, 1999b, 2005; Kosciulek, Merz 2001), at least in part, by increasing their involvement in decision making (IOM 2001). Besides healthcare patients, other consumers are also often observed to complain that companies exert too much control over their daily lives, and many endeavor to participate more actively in the marketplace (Bernstein et al. 2000; Holt 2002).

The model in Figure 1 illustrates the logical sequence of the components that are critical to the determination of successful service recovery. By expanding a portion of Zeithaml and Bitner's (2000) model - namely the customer who complains to a service provider - the model of service recovery is proposed. According to the model, the degree of complainant-felt empowerment during service recovery determines both the level of complainant's cognitive/affective response and the level of subsequent complaint satisfaction. Beside the direct effect of CE on complaint satisfaction, complainant affect and cognitions are positioned as the partial mediators of this relationship (Lassar et al. 2000; Maute, Dube 1999; Mittal, Lassar 1998; Parasuraman et al. 1985, 1988; Tax et al. 1998; Westbrook, Oliver 1991; Zeelenberg, Pieters 1999; Zeithaml, Bitner 2000). In addition to the mediating effects of the three cognitive/affective concepts on complaint satisfaction, the model also proposes all two-way interactions among cognitive/affective constructs (Essén, Wikström 2008; Katz et al. 1991; Parasuraman et al. 1985). A review of the literature supporting the relationships posited in Figure 1 follows.

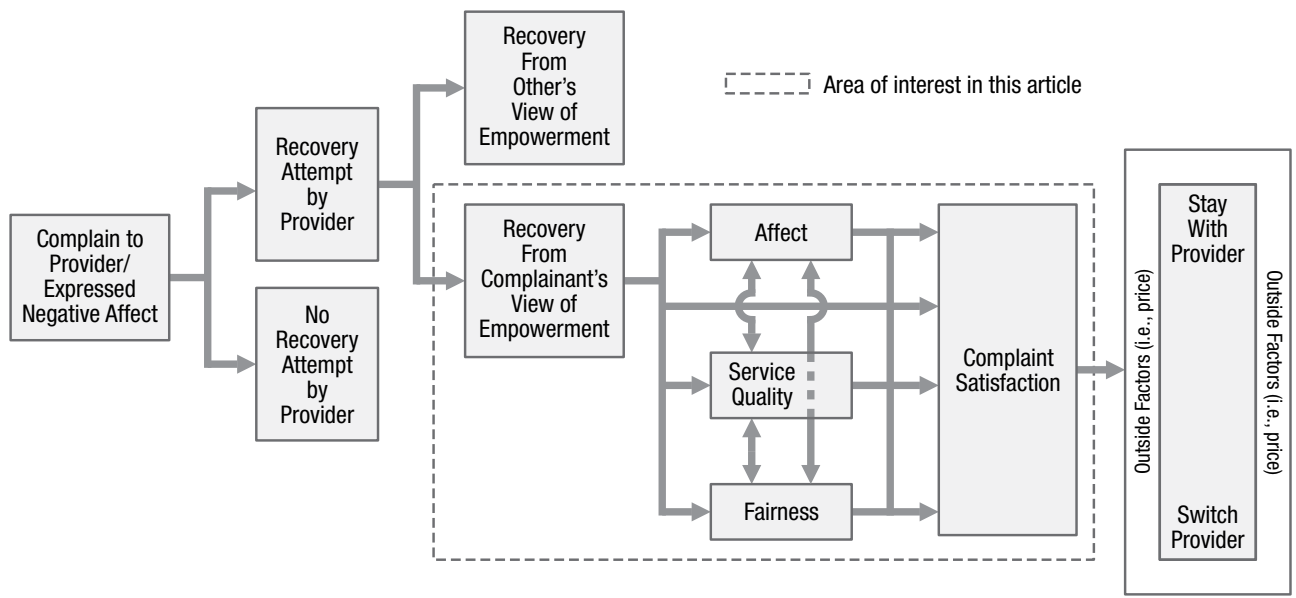

Fig. 1. The service recovery model 


\section{Empowerment}

This section outlines key results from the study of the empowerment concept in various streams of literature. Building on this brief outline, the construct definition of $\mathrm{CE}$ in service recovery context is presented next.

\subsection{Studying empowerment}

As empowerment historically is a term used across a wide range of disciplines, its definitions and interpretations vary with destination discipline (Lincoln et al. 2002).

\subsubsection{Empowerment in non-management disciplines}

The issue of empowerment in fields other than management has largely been centered on women, minorities, education, and politics and viewed from the perspective of powerlessness and oppression (Lincoln et al. 2002). In short, the overarching contention in these disciplines is that the purpose of empowerment of group A (e.g., women or minority) is not to take power from group B (e.g., men or majority); rather, the goal of group A is to develop its own power while respecting group B for what it is (Hall 1992). Thus, "empowerment is not a zerosum game" (Saltman 1994: 8) but rather a positive-sum game (Dunlop 1958).

\subsubsection{Organizational empowerment}

Within the management discipline, organizational empowerment is synonymous with employee empowerment and is seen as the route to improved work and organizational performance (Wall et al. 2002). While some scholars appear to hold a relatively uniform understanding of employee empowerment across settings (e.g., Lee, Koh 2001), others find it as individually, contextually, and variably defined (e.g., Zimmerman 1995). Nevertheless, it appears to have two broad uses (Lee, Koh 2001; Menon 2001; Wall et al. 2002). First is the empowering 'behavior of a supervisor' who empowers his/her subordinates and who is the cause of empowerment. Second is 'psychological empowerment' (PE) which is the consequential perception of a subordinated resulting from his/ her supervisors' act of empowering. PE is manifested in 4 cognitions: meaning (value of work goal or purpose), competence (self-efficacy), self-determination (autonomy in initiation and continuation of work behaviors), and impact (influence of work outcomes). PE's antecedents are self-esteem, information, and rewards.

While Lee and Koh (2001) view PE as a unique concept, many similar phrases exist in the literature. These include authority delegation, motivation, self-efficacy, job enrichment, employee ownership, autonomy, self-determination, self-management, selfcontrol, self-influence, self-leadership, high-involvement, and participative management (Lee, Koh 2001). In addition to a distinction between an empowering 'behavior of a supervisor' and PE, differentiation is also made between empowering and empowered organizations. While empowering organizations produce PE for individual members as part of their organizational process, empowered organizations influence the larger system of which they are a part (Peterson, Zimmerman 2004). 


\subsubsection{Customer empowerment}

As organizations often regard customers as co-producers (Edvardsson et al. 1994) or 'partial' employees (Kelley et al. 1992), CE is a natural and logical extension of employee empowerment. The most significant contribution in this area has been in the literature covering NPD and healthcare services (i.e., via the recent introduction of the consumer-directed theory of empowerment [CDTE]).

In CDTE, CE may be broadly defined as "the transfer of power and control over the values, decisions, choices, and directions of human services from external entities to the consumers of services, resulting in increased motivation to participate and succeed and a greater dignity for the consumer" (West, Parent 1992, as cited in Kosciulek 1999b: 4). Therein, CE involves both internal-psychological and situational-social factors (Kosciulek 2005). Internal-psychological aspects include a sense of control, competence, responsibility, participation, and future orientation. Situational-social aspects include control over resources, interpersonal skills, work, organizational skills, and savvy. However, there are two main reasons why CDTE is limited in its ability to explain service recovery strategies. First, CDTE was developed specifically as a theoretical framework for research in healthcare rehabilitation services, rendering its application to other services questionable. Second, CDTE's focus on improving the delivery of initial services neglects important service recovery issues resulting from the unique nature of the complainant-provider relationship. Despite its limitations in the service recovery context, CDTE provides some useful conceptual and philosophical guidance for this study. In short, the major tenets of the CDTE - as it applies to this research - are that (1) greater consumer control in service production and delivery will lead to the perception of empowerment (Kosciulek 1999a, 1999b, 2005; Kosciulek, Merz 2001), and (2) individuals should be free to make their own decisions about the management of their own lives (Kosciulek 1999a, 1999b, 2005).

In NPD research, empowered customers (i.e., those who participate in the new product selection process) show stronger demand for final products than non-empowered customers (i.e., those who do not participate in the new product selection process; Fuchs et al. 2010). As customer preferences have become increasingly heterogeneous in many markets, and customers progressively demand customized products (Gilmore, Pine 1997), empowerment-to-select strategies allow customers to experience the feeling of having an impact in the new product selection process. Moreover, self-tailored products create higher benefits for customers than standard products because they deliver a closer preference fit (Franke et al. 2009). However, a major problem arises when customer empowerment in the area of NPD is used to study CE in the service recovery context. Namely, in NPD consumers are empowered to select the brand new product concepts to be produced by the manufacturer at some point in the future. Since NPD and service recovery vastly differ (in terms of intangibility, heterogeneity, inseparability, and perishability), both the usefulness and the power of NPD-related arguments in the service recovery context is dubious. 
In addition to the healthcare and NPD views of customer empowerment, McGregor (2005) offers an educational perspective on customer empowerment. Accordingly, giving someone information is enabling them to do something but not empowering them. Hence a truly empowered customer must create and hold an inner perception of power and authority to take action. This is accomplished through encouraging and enabling of individuals to do things and to think for themselves. By teaching people to act and think independently, their abilities and competence increase, they become more self-reliant, and they perceive themselves as empowered to take action and control of conditions affecting their daily lives.

In sum, common dimensions shared by all approaches - community, organizational, and customer - to the study of empowerment are (1) access to information, (2) participation and influence in decision-making, and (3) competence to make decisions. Moreover, the review of community, organizational, and customer empowerment literature suggests that empowerment at the individual level denotes either (1) an empowering behavior of person A who empowers person B and who is the cause of empowerment or (2) 'psychological empowerment' which is the consequential perception of a person B resulting from person A's act of empowering (e.g., Kosciulek 1999a, 1999b; McGregor 2005; Menon 2001; Peterson, Zimmerman 2004; Spreitzer 1995). Overall, while CE in the context of healthcare and NPD is not new per se, CE in service recovery encounters (i.e., complainant empowerment) is a new concept.

\subsection{Construct definition of $\mathrm{CE}$ in the service recovery context}

Review of the various streams of empowerment research outlined above reveals that, at an individual level in the context of service recovery, the three underlying theoretical components in CE are (1) information, (2) competence, and (3) control/influence.

Information is conceptualized as both provision of and access to information by the empowered agent, to and from the external agent or organization respectively (Khwaja 2005). When complainants in service recovery are empowered, they are both able to provide information about their own preferences and gain information from the service provider that may in turn enhance their capacity to make optimal choices. Both types of information are likely to lead to increased welfare of the empowered complainant.

Competence, or self-efficacy, is conceptualized as an individual's belief in her/his capability to "mobilize the motivation, cognitive resources, and courses of action needed to meet given situational demands" (Wood, Bandura 1989: 408). People tend to avoid activities they perceive as exceeding their coping skills. Conversely, they get involved in situations they perceive as within their power to handle (Menon 2001). When complainants in service recovery are empowered, they both have the capacity to articulate information about their preferences and use information from service provider to make optimal choices.

Control or influence is conceptualized as an agent's ability to influence a particular decision, and knowledge that s/he has this ability (Khwaja 2005). By giving greater influence in a decision to the agent whose perspective matters most for outcome of the 
decision, we are ensuring that this agent has a high incentive to supply her/his perspective. All parties involved experience higher overall benefits from such a decision.

In sum, we define CE as a strategy firms use to give complainants sufficient information and a sense of control and competence over its service recovery, allowing them to self-select remedies the company will use to correct a wrong. Stated differently, an empowered complainant is defined as a consumer who has information, competence, and influence in the service recovery process. CE is manifested in three dimensions (information, competence, and influence) that are argued to combine additively to create an overall construct of CE in service recovery. Additionally, empowerment is a continuous variable wherein complainants are more empowered or less empowered, rather than empowered or not empowered (Spreitzer 1995). Thus, the decrease in any single dimension will reduce - albeit not completely eliminate - the overall degree of felt empowerment.

\section{The CE - affect relationship}

While consumer affect has received some research attention in marketing via the concept of Customer Relationship Marketing (CRM; see Special Issue on Relationship Marketing 1995), the issue of complainants' emotional responses in service recovery research has been largely ignored (Chebat, Slusarczyk 2005).

The term 'affect' usually refers to a wide range of emotions, moods, feelings, and drives generated by individuals as they decipher events around them (Maute, Dube 1999). We expect this prediction to arise because the underlying emotional states might be influenced by the complainant's participation in service recovery. First, we assume that empowerment-to-control strategies allow complainants to experience the feeling of 'having an influence' (the direct psychological outcome of empowerment strategies). Perceived influence refers to the degree to which a complainant has the ability to control certain outcomes, and knowledge that s/he has this ability (Khwaja 2005). It is plausible that empowered complainants believe that they have a stronger influence on a company and its service recovery acts than non-empowered complainants, who have nearly no say in a firm's service recovery process.

Second, because of complainants' ability to participate in service recovery (and thus have an influence), we expect empowered complainants to experience increased beliefs of self-efficacy (a 'can-do' attitude) and increased feelings of responsibility, which might lead to stronger feelings of ownership (Pierce et al. 2001). This is consistent with the literature on empowerment in general: When people are allowed to participate actively in decision making and perceive that they may influence the outcome, they assume psychological ownership of such decisions because they are partly responsible for the outcome (i.e., the final decision becomes 'their decision' (Agarwal, Ramaswami 1993; Hunton 1996), and this tends to elicit positive feelings (Barki, Hartwick 1994; Hui, Bateson 1991), such as happy/content and pleasantly surprised (Westbrook, Oliver 1991).

A recent classroom discussion with a group of tourism and hospitality students following a guided visit to a leading international hotel brand offers further insight into the 
CE - affect relationship. During the hotel visit, one of the students had inquired with the HR manager about the most recent customer complaint and the hotel's response to it. The manager described an encounter where a guest called the front desk, complaining that he had been awakened by the lawn mowing noise on hotel property. The disgruntled guest first received an apology, and was then told that the problem would be taken care of, and it sure was (i.e., the lawn mower was shut off within minutes). Later that same day, a front desk shift manager contacted the same guest, apologized for the mishap once again, and offered him a complimentary one-day wellness and spa package at the hotel (package otherwise not included in guest's room price and valued at $€ 55)$. In the ensuing classroom discussion later that week, the students were asked what they thought about the complementary wellness and spa package furnished to the guest. Surprisingly, one student lamented that she did not care much for wellness and spa services. Her remark immediately prompted another student's commentary whereby he rejoiced over the possibility of receiving compensation in the form of a free use of wellness and spa services. This short narrative exemplifies how even the best intended service remedy can produce starkly opposed emotional reactions. Based on these ideas, the following proposition is formulated:

Proposition 1: In a service recovery context, the affective responses of empowered complainants will be more positive than those of non-empowered complainants.

\section{The CE - service quality effect}

Perceived service quality may be defined as the customer's assessment of the relative inferiority/superiority of the provider organization and its services (Bitner, Hubbert 1994). At the individual customer level, numerous studies have shown that perceived service quality is a partial determinant of satisfaction (Lassar et al. 2000; Mittal, Lassar 1998; Parasuraman et al. 1985, 1988).

The two most popular schools of thought on service quality are the North American and the Nordic European (Ekinci et al. 1998; Weber, Roehl 2001). The North American School is represented by the SERVQUAL model (Parasuraman et al. 1985, 1988), while the Technical/Functional Quality (T/FQ) framework embodies the Nordic European School (Grönroos 1984). The SERVQUAL instrument is a multiple-item scale designed to determine a perception of service quality as a function of the difference between consumer's expectations and actual service performance (Parasuraman et al. 1985). However, despite its widespread use, the SERVQUAL instrument has generated considerable criticism in most replication studies, both on theoretical and operational grounds (Cronin, Taylor 1992).

In the T/FQ framework - representing the Nordic European School - service quality is believed to consist of two dimensions - technical or outcome quality and functional or process quality (Grönroos 1984; Lassar et al. 2000; Mittal, Lassar 1998). While technical quality refers to what is provided (e.g., the cleanliness of the room), functional quality considers how it is provided (e.g., the care and/or manners of the service provider). This effect can be derived because the underlying service quality perceptions might be 
influenced by the complainant's participation in the service recovery process. First, a typical complainant will need either to be physically present for a service to be remedied or will have to provide information as a prerequisite. Therefore, the quality of the ensuing service recovery will then be dependent, at least in part, on the way in which the complainant interacts with the service provider (Zeithaml et al. 1988). Continuing with the earlier example from a students' hotel visit, a manager's offer of a complimentary one-day wellness and spa package to the disgruntled guest did not come about as a result of the guest's participation in the recovery process. Instead, a manager presented the guest with a compensation resembling a take it or leave it approach. As evidenced by the two students' reactions in the later classroom discussion about the incident, the hotel's apparent hit or miss recovery remedy can seriously damage its perceived service quality. A female student who stated that she did not care much for wellness and spa services is likely to interpret the hotel's compensation as evidence of inferior service quality.

Second, we assume that empowerment-to-participate strategies allow complainants to experience the sense of 'receiving a customized service.' Providing high-quality service means customizing as much as possible to what the individual customer desires (Rust, Chung 2006). Customization, or personalization, is a process that often requires extensive customer participation (Simonson 2005) to deliver a tailored solution to that customer (Murthi, Sarkar 2003). This is consistent with Ennew and Binks (1999), who argued a decade ago that participation of small businesses in services provided by banks has a positive impact on quality. It is also consistent with the logic behind employee empowerment in the service sector literature, where empowerment of front-line staff can be fundamental to achieving and improving the level of service quality (Berry, Parasuraman 1992). Based on these ideas, we expect empowered complainants to perceive a higher level of service quality than non-empowered complainants because participation in the recovery process will induce strong perceptions of high quality service recovery.

Proposition 2: In a service recovery context, empowered complainants will perceive a higher level of service quality than non-empowered complainants.

\section{The CE - fairness effect}

Fairness, also referred to as equity (De Ruyter, Wetzels 2000) or justice (Maxham, Netemeyer 2003), is defined as customer's fairness comparison of an exchange between themselves and other entities (Maxham, Netemeyer 2003; Oliver 1997). Customers evaluate equity via three dimensions: distributive justice, procedural justice, and interactional justice (Blodgett et al. 1997; Choi, Mattila 2004; Clemmer, Schneider 1996; Smith et al. 1999; Sparks, McColl-Kennedy 2001; Tax et al. 1998; Zeithaml, Bitner 2000).

Distributive justice refers to the perceived fairness of the redress (refund, exchange, discount on future purchase, etc., or some combination thereof) offered to customers to resolve their complaints (Blodgett et al. 1997). In a service recovery context, perceptions of fair outcomes rest with individual complainants and reflect their impressions of tangible outcomes. Hence, should complainants be permitted to select among several 
types of remedies or, even better, invited to propose a redress of their own choosing, they might like their outcome better and perceive it as fairer than non-empowered complainants who may neither pick nor propose an outcome. Such an argument is partially supported by the literature on empowerment in general. That is, when people are allowed to participate actively in decision making and perceive that they may influence the outcome, they assume psychological ownership of such decisions because they are partly responsible for the outcome (i.e., the final decision becomes 'their decision' (Agarwal, Ramaswami 1993; Hunton 1996).

Procedural justice entails perceived fairness of the policies and rules used by decisionmakers in arriving at the outcome (Lind, Tyler 1988; Smith et al. 1999). Fair procedures are based on accurate information, representative of all parties' interests, flexible, and allow concerned parties some control over the decision (Blodgett et al. 1997; Goodwin, Ross 1992; Greenberg, Folger 1983; Leventhal et al. 1980; Tax et al. 1998). Therefore, when complainants are given the opportunity to voice their interests during service recovery, they then might perceive firm's empowering procedures and rules as fairer than non-empowered complainants whose voices cannot be heard.

Interactional justice corresponds to the perceived fairness of the interpersonal treatment customers receive during service recovery (Blodgett et al. 1997; Tax et al. 1998). Fair interactions include offer of an apology, acceptance of blame, provision of explanation, empathy, assurance, politeness, friendliness, sensitivity, interest, honesty, directness, and effort (Blodgett et al. 1997; Goodwin, Ross 1992; Parasuraman et al. 1985). Thus, service providers who show interest in and are sensitive towards complainant's viewpoint might be perceived as interacting more fairly with their customers than nonempowered complainants whose viewpoints are neglected. Continuing with the earlier example of students' classroom discussion following a hotel visit, the reaction by a female student suggests she would not deem the compensation offered as fair. Since free wellness and spa pass does not represent something she is interested in, she will likely interpret the hotel's compensation as evidence of hotel's insensitivity towards her view and, thus, unfair. Building on these ideas, we expect the fairness perceptions of empowered customers to be more positive than those of non-empowered customers because fair recovery procedures and interactions will result in strong perceptions of a righteous service recovery.

Proposition 3: In a service recovery context, the fairness perceptions of empowered customers will be more positive than those of non-empowered customers.

\section{The CE - complaint satisfaction relationship}

According to Oliver (1997), "satisfaction is the consumer's fulfillment response. It is a judgment that a product or service feature, or the product or service itself, provides a pleasurable level of consumption-related fulfillment" (p. 13). In more practical terms, satisfaction is customer's assessment of a product or service in terms of whether that product or service has met his or her needs and expectations. Thus dissatisfaction with a product or service is attributed to customer's unmet needs and expectations. Customer 
satisfaction is influenced by specific product or service features, perceptions of quality, customers' emotional responses, their attributions for service success or failure, and their perceptions of equity or fairness (Zeithaml, Bitner 2000).

In the context of service recovery, Stauss (2002) replaced Oliver's global definition of satisfaction with 'complaint satisfaction', which refers to complainant's satisfaction with a company's response to her/his complaint. In line with Grönroos' (1984) differentiation between technical and functional service quality (T/FQ), complaint satisfaction is believed to consist of outcome (technical) satisfaction and process (functional) satisfaction (Lassar et al. 2000; Stauss 2002). While the former refers to the evaluation of what the complainant gets from the company (i.e., 'outcome complaint satisfaction'), the latter refers to complainant's satisfaction with how his/her complaint is handled (i.e., 'process complaint satisfaction'; Lassar et al. 2000; Stauss 2002). As customers increasingly demand that companies open up more of their processes to customers' active participation (e.g., Firat, Venkatesh 1995), complainants are likely to assess their satisfaction or dissatisfaction with an underlying recovery encounter in terms of whether that encounter has met their needs and expectations for participation. Continuing with the earlier example of a female student's remark during a classroom discussion following a hotel visit, compensation in the form of a free wellness and spa pass did not meet her needs and expectations. Thus, she is likely to be dissatisfied with a hotel's response to the complaint.

The proposed impact of empowerment on those who are empowered is well documented in the services management literature in general, which suggests that empowerment of frontline staff can improve both customer satisfaction and employee attitudes and behaviour (Ashness, Lashley 1995; Lashley, McGoldrick 1994; Rafiq, Ahmed 1998; Ripley, R. E., Ripley, M. J. 1992; Van Looy et al. 1998). If this relationship also holds for complainants in service recovery encounters, firms may do well to empower them. With these ideas in mind, we expect complainants experiencing firms' empowermentto-participate recovery strategies to perceive such recoveries as more satisfactory than complainants who have their desires thwarted or redirected by those with power.

Proposition 4: In a service recovery context, empowered complainants will perceive higher levels of complaint satisfaction than non-empowered complainants.

\section{Discussion and conclusions}

The satisfactory resolution of customer complaints requires empowering those (i.e., complainants) who have traditionally been given little power to effect how their service recovery encounter unfolds. Studies on CE in service recovery appear to be particularly relevant at a time when consumers increasingly gripe that companies exert too much control over their daily lives, and many endeavor to participate more actively in the marketplace (Bernstein et al. 2000; Holt 2002). In addition, service recovery is ideally suited to the introduction of $\mathrm{CE}$ because complainants are more emotionally involved, have hightened expectations, and have a greater vested interest in service recovery than customers in ordinary (i.e., initial, non-recovery) service encounters. It is, therefore, 
surprising that the notion of $\mathrm{CE}$ has received little attention in the service recovery literature. This study has attempted, in part, to fill a gap in the literature by proposing an integrative model of service recovery from the complainant's point of view that can serve as the theoretical foundation for the development and evaluation of service recovery policy and complaint satisfaction.

In this framework, empowered complainant is conceptualized as someone who has information, competence, and influence in service recovery. The proposed model suggests that CE from complainant's perspective produces four major service recovery outcomes: customer affect, service quality, fairness, and complaint satisfaction. This framework offers important theoretical implications for service recovery research as well as practical guidance for CE development in the service recovery context. Theoretically, this study represents a valuable attempt to expand the framework for research on service recovery. That is, conventional research on CE usually focuses on devising tools and techniques to develop new consumer products or to improve the delivery of initial services in the healthcare setting. While these studies have identified and developed useful means that manufacturing and healthcare organizations can utilize for NPD and initial service delivery, how to improve service recovery efforts through empowering complainants has rarely been fully examined. By providing a customer's view of CE in service recovery, this study demonstrates an important, albeit preliminary, step toward a research theme focusing on $\mathrm{CE}$ for service organizations within a service recovery context.

Practically, this study offers guidance for managers in service organizations in connection to the issue of realism of empowering complainants. In this sense, CE should not be viewed in isolation from compensation. Instead, managers should think of CE as a vehicle with a potential to produce compensation that is individually tailored for each complainant. By offering tailored solutions to each guest's problem via $\mathrm{CE}$, managers might significantly increase their chances of turning disgruntled guests into engaged and loyal customers. In response to a possible critique in case of outrageous requests by complainants during service recovery, there is some evidence suggesting that customers may experience consumer guilt if overly compensated (Dedeoglu, Kazancoglu 2010). For instance, Domino's Pizza (the U.S.-based pizza chain) - following a discovery that customers were not comfortable asking for a free pizza if the driver narrowly missed a delivery deadline - changed its service guarantee from 'Delivery within 30 minutes or receive a free pizza' to 'Delivery within 30 minutes or $\$ 3.00$ off the purchase price' (Tax et al. 1998; Zeithaml, Bitner 2000). This rather anecdotal evidence suggests that before any empowerment strategy is deployed, the effect of varying levels of compensation on complainant's feeling of dis/comfort must undergo empirical scrutiny.

Although this study established a foundation for research on CE in service recovery, further research is required to confirm or challenge the various aspects of the proposed framework. First, future research should strive to develop and validate a new measurement instrument of CE in service recovery. Following the operationalization and validation of the CE construct, the second step would be to empirically test whether CE has a positive impact on complainant cognitions/affect and complaint satisfaction. Third, 
future empirical research should also examine potential differences between different types of services, i.e. whether $\mathrm{CE}$ is more important in the service recovery of certain services while less important for others. Namely, the degree of interpersonal contact in buyer-seller interactions seems important in the evaluation of technical and functional aspects of services. Functional or process quality significantly and positively affects satisfaction in high contact services whereas technical or outcome quality is more important in low contact services (Mittal, Lassar 1998).

In high contact services - such as hotels, restaurants, airline travel, and retail banking customers visit the service facility and remain throughout the service delivery (Lovelock, Wirtz 2004). Moreover, high contact services involve an active (i.e., direct) and relatively intense contact between customers and service personnel (Lovelock, Wirtz 2004; Mittal, Lassar 1998). In contrast, low contact services (e.g., car repair, insurance, internet banking) feature little or no physical contact with service personnel, and contact is usually at arm's length through electronic (e.g., Internet) or physical distribution channels (Lovelock, Wirtz 2004). Overall, service on one's possessions is a 'lower' contact service, while service on the person himself/herself is a 'higher' contact service (Mittal, Lassar 1998). Last, but not least, future research should also examine potential differences between different cultures, i.e. whether CE is more important in the service recovery of certain countries and cultures while less important for others.

\section{References}

Agarwal, S.; Ramaswami, S. N. 1993. Affective organizational commitment of salespeople: an expanded model, Journal of Personal Selling and Sales Management 13(2): 49-70.

Ashness, D.; Lashley, C. 1995. Empowering service workers at Harvester restaurants, Personnel Review 24(8): 17-32. http://dx.doi.org/10.1108/00483489510147565

Barki, H.; Hartwick, J. 1994. Measuring user participation, user involvement, and user attitude, MIS Quarterly 18(1): 59-82. http://dx.doi.org/10.2307/249610

Becker, C. 2000. Service recovery strategies: the impact of cultural differences, Journal of Hospitality and Tourism Research 24(4): 526-538. http://dx.doi.org/10.1177/109634800002400407

Bernstein, A.; Arndt, M.; Zellner, W.; Coy, P. 2000. Too much corporate power?, Business Week 11(September): 52-60.

Berry, L. L.; Parasuraman, A. 1992. Service marketing starts from within, Marketing Management 1(1): 25-34.

Bitner, M. J.; Booms, B. H.; Mohr, L. A. 1994. Critical service encounters: the employee's viewpoint, Journal of Marketing 58(October): 95-106. http://dx.doi.org/10.2307/1251919

Bitner, M. J.; Hubbert, A. R. 1994. Encounter satisfaction versus overall satisfaction versus quality: the customers voice, in Rust, R. T.; Oliver, R. L. (Eds.). Service Quality: New Directions in Theory and Practice. Thousand Oaks, CA: Sage Publications.

Blodgett, J. G.; Hill, D. J.; Tax, S. S. 1997. The effects of distributive, procedural, and interactional justice on postcomplaint behavior, Journal of Retailing 73(2): 185-210.

http://dx.doi.org/10.1016/S0022-4359(97)90003-8

Chebat, J.-C.; Slusarczyk, W. 2005. How emotions mediate the effects of perceived justice on loyalty in service recovery situations: an empirical study, Journal of Business Research 58(5): 644-673. http://dx.doi.org/10.1016/j.jbusres.2003.09.005 
Choi, S.; Matilla, A. S. 2004. Hotel revenue management and its impact on customers' perceptions of fairness, Journal of Revenue and Pricing Management 2(4): 303-314.

http://dx.doi.org/10.1057/palgrave.rpm.5170079

Clemmer, E. C.; Schneider, B. 1996. Fair service, in Brown, S. W.; Bowen, D. A.; Swartz, T. (Eds.). Advances in Services Marketing and Management, vol. 5. Greenwich: JAI Press.

Cronin, J. J.; Taylor, S. A. 1992. Measuring service quality: a reexamination and extension, Journal of Marketing 56(3): 55-68. http://dx.doi.org/10.2307/1252296

Dedeoglu, A. O.; Kazancoglu, I. 2010. The feelings of consumer guilt: a phenomenological exploration, Journal of Business Economics and Management 11(3): 462-482.

http://dx.doi.org/10.3846/jbem.2010.23

De Ruyter, K.; Wetzels, M. 2000. Customer equity considerations in service recovery: a crossindustry perspective, International Journal of Service Industry Management 11(1): 91-108.

http://dx.doi.org/10.1108/09564230010310303

Dunlop, J. T. 1958. Industrial Relations Systems. New York: Holt.

Edvardsson, B.; Thomasson, B.; Ovretveit, J. 1994. Quality of Service. London: Mcgraw-Hill.

Ennew, C. T.; Binks, M. R. 1999. The impact of participative service relationships on quality, satisfaction and retention: an exploratory study, Journal of Business Research 46(2): 121-132. http://dx.doi.org/10.1016/S0148-2963(98)00016-2

Ekinci, Y.; Riley, M.; Fife-Schaw, C. 1998. Which school of thought? The dimensions of resort hotel quality, International Journal of Contemporary Hospitality Management 10(2): 63-67. http://dx.doi.org/10.1108/09596119810207200

Ekiz, E. H.; Arasli, H. 2007. Measuring the impacts of organizational responses: case of northern cyprus hotels, Managing Global Transitions 5(3): 271-287.

Essén, A.; Wikström, S. 2008. The role of emotion in service evaluation: senior citizens' assessments of long-term care services, Managing Service Quality 18(2): 147-162.

http://dx.doi.org/10.1108/09604520810859201

Firat, A. F.; Venkatesh, A. 1995. Liberatory postmodernism and the reenchantment of consumption, Journal of Consumer Research 22(3): 239-267. http://dx.doi.org/10.1086/209448

Fornell, C.; Wernerfelt, B. 1987. Defensive marketing strategy by consumer complaint management: a theoretical analysis, Journal of Marketing Research 24(4): 337-346.

http://dx.doi.org/10.2307/3151381

Franke, N.; Keinz, P.; Steiger, J. 2009. Testing the value of customization: when do customers really prefer products tailored to their preferences?, Journal of Marketing 73(September): 103-121. http://dx.doi.org/10.1509/jmkg.73.5.103

Fuchs, C.; Prandelli, E.; Schreier, M. 2010. The psychological effects of empowerment strategies on consumers' product demand, Journal of Marketing 74(January): 65-79.

http://dx.doi.org/10.1509/jmkg.74.1.65

Fuchs, C.; Schreier, M. 2011. Customer empowerment in new product development, Journal of Product Innovation Management 28(1): 17-32.

http://dx.doi.org/10.1111/j.1540-5885.2010.00778.x

Gilmore, J. H.; Pine, B. J. 1997. The four faces of mass customization, Harvard Business Review 75(January-February): 91-101.

Goodwin, C.; Ross, I. 1992. Consumer responses to service failures: influence of procedural and interactional fairness perceptions, Journal of Business Research 25: 149-163.

http://dx.doi.org/10.1016/0148-2963(92)90014-3

Greenberg, J.; Folger, R. 1983. Procedural justice, participation and the fair process effect in groups and organizations, in Paulus, P. B. (Ed.). Basic Group Processes. New York: SpringerVerlag. http://dx.doi.org/10.1007/978-1-4612-5578-9_10 
Grönroos, C. 1984. A service quality model and its marketing implications, European Journal of Marketing 18(4): 36-44. http://dx.doi.org/10.1108/EUM0000000004784

Grönroos, C. 1988. Service quality: the six criteria of good perceived service quality, Review of Business 9(3): 10-13.

Hall, C. M. 1992. Women and Empowerment: Strategies for Increasing Autonomy. Washington: Hemisphere.

Hart, C. W. L. 1988. The power of unconditional service guarantees, Harvard Business Review 66(4): 54-62.

Hart, C. W. L.; Heskett, J. L.; Sasser, W. E. Jr. 1990. The profitable art of service recovery, Harvard Business Review 68(4): 148-156.

Hoffman, K. D.; Bateson, J. E. G. 1997. Essentials of Services Marketing. New York: The Dryden Press.

Holt, D. B. 2002. Why do brands cause trouble? A dialectical theory of consumer culture and branding, Journal of Consumer Research 29(June): 70-90. http://dx.doi.org/10.1086/339922

Hui, M. K.; Bateson, J. E. G. 1991. Perceived control and the effects of crowding and consumer choice on the service experience, Journal of Consumer Research 18(September): 174-184.

http://dx.doi.org/10.1086/209250

Hunton, J. E. 1996. User participation in defining system interface requirements: an issue of procedural justice, Journal of Information Systems 10(1): 27-47.

Institute of Medicine. 2001. Crossing the Quality Chasm: a New Health System for the $21^{\text {st }}$ Century. Washington, D. C.: National Academy Press.

Katz, K.; Larson, B.; Larson, R. 1991. Prescription for the waiting in line blues: entertain, enlighten, and engage, Sloan Management Review 32(2): 44-53.

Kelley, S. W.; Skinner, S. J.; Donnelly, J. H. 1992. Organizational socialization of service customers, Journal of Business Research 25(3): 197-214.

http://dx.doi.org/10.1016/0148-2963(92)90029-B

Khwaja, A. I. 2005. Measuring empowerment at the community level: an economist's perspective, in Narayan, D. (Ed.). Measuring Empowerment: Cross-disciplinary Perspectives. Washington, D. C.: World Bank.

Kosciulek, J. F. 1999a. Consumer direction in disability policy formulation and rehabilitation service delivery, Journal of Rehabilitation 65(2): 4-9.

http://dx.doi.org/10.1177/00343552050490010501

Kosciulek, J. F. 1999b. The consumer-directed theory of empowerment, Rehabilitation Counseling Bulletin 42(3): 196-213.

Kosciulek, J. F. 2005. Structural equation model of the consumer-directed theory of empowerment in a vocational rehabilitation context, Rehabilitation Counseling Bulletin 49(1): 40-49. http://dx.doi.org/10.1177/003435520104400403

Kosciulek, J. F.; Merz, M. 2001. Structural analysis of the consumer-directed theory of empowerment, Rehabilitation Counseling Bulletin 44(4): 209-216.

Lashley, C.; McGoldrick, J. 1994. The limits of empowerment: a critical assessment of human resource strategy for hospitality operations, Empowerment in Organisations 2(3): 25-38.

http://dx.doi.org/10.1108/09684899410071671

Lassar, W. M.; Manolis, C.; Winsor, R. D. 2000. Service quality perspectives and satisfaction in private banking, Journal of Services Marketing 14(3): 244-271.

http://dx.doi.org/10.1108/08876040010327248

Lee, M.; Koh, J. 2001. Is empowerment really a new concept?, International Journal of Human Resource Management 12(4): 684-695. 
Leventhal, J.; Karuza, J.; Fry, W. R. 1980. Beyond fairness: a theory of allocation preferences, in Mikula, G. (Ed.). Justice and Social Interaction. New York: Springer-Verlag.

Liljander, V.; Strandvik, T. 1997. Emotions in service satisfaction, International Journal of Service Industry Management 8(2): 148-169. http://dx.doi.org/10.1108/09564239710166272

Lincoln, N. D.; Travers, C.; Ackers, P.; Wilkinson, A. 2002. The meaning of empowerment: the interdisciplinary etymology of a new management concept, International Journal of Management Reviews 4(3): 271-290. http://dx.doi.org/10.1111/1468-2370.00087

Lind, E. A.; Tyler, T. R. 1988. The Social Psychology of Procedural Justice. New York: Plenum Press.

Lovelock, C.; Wirtz, J. 2004. Services Marketing: People, Technology, Strategy. $5^{\text {th }}$ ed. Upper Saddle River: Prentice Hall.

Maute, M. F.; Dube, L. 1999. Patterns of emotional responses and behavioural consequences of dissatisfaction, Applied Psychology: an International Review 48(3): 349-366.

http://dx.doi.org/10.1111/j.1464-0597.1999.tb00006.x

Maxham, J. G. III.; Netemeyer, R. G. 2003. Firms reap what they sow: the effects of shared values and perceived organizational justice on customers' evaluations of complaint handling, Journal of Marketing 67(January): 46-62. http://dx.doi.org/10.1509/jmkg.67.1.46.18591

McGregor, S. L. T. 2005. Sustainable consumer empowerment through critical consumer education: a typology of consumer education approaches, International Journal of Consumer Studies 29(5): 437-447. http://dx.doi.org/10.1111/j.1470-6431.2005.00467.x

Menon, S. T. 2001. Employee empowerment: an integrative psychological approach, Applied Psychology: an International Review 50(1): 153-180. http://dx.doi.org/10.1111/1464-0597.00052

Mittal, B.; Lassar, W. M. 1998. Why do customers switch? The dynamics of satisfaction versus loyalty, Journal of Services Marketing 12(3): 177-194. http://dx.doi.org/10.1108/08876049810219502

Mittal, V.; Anderson, E. W.; Sayrak, A.; Tadikamalla, P. 2005. Dual emphasis and the long-term financial impact of customer satisfaction, Marketing Science 24(4): 544-555.

http://dx.doi.org/10.1287/mksc.1050.0142

Murthi, B. P. S.; Sarkar, S. 2003. The role of the management sciences in research on personalization, Management Science 49(10): 1344-1362. http://dx.doi.org/10.1287/mnsc.49.10.1344.17313

Oliver, R. L. 1997. Satisfaction. A Behavioral Perspective on the Consumer. New York: McgrawHill.

Parasuraman, A.; Zeithaml, V. A.; Berry, L. L. 1985. A conceptual model of service quality and its implications for future research, Journal of Marketing 49(Fall): 41-50.

http://dx.doi.org/10.2307/1251430

Parasuraman, A.; Zeithaml, V. A.; Berry, L. L. 1988. SERVQUAL: a multiple-item scale for measuring consumer perceptions of service quality, Journal of Retailing 64(1): 12-40.

Peterson, N. A.; Zimmerman, M. A. 2004. Beyond the individual: toward a nomological network of organizational empowerment, American Journal of Community Psychology 34(1/2): 129-145. http://dx.doi.org/10.1023/B:AJCP.0000040151.77047.58

Pierce, J. L.; Kostova, T.; Dirks, K. T. 2001. Toward a theory of psychological ownership in organizations, Academy of Management Review 26(2): 298-310.

Rafiq, M.; Ahmed, P. K. 1998. A customer-oriented framework for empowering service employees, The Journal of Services Marketing 12(5): 379-396. http://dx.doi.org/10.1108/08876049810235423

Ripley, R. E.; Ripley, M. J. 1992. Empowerment, the cornerstone of quality: empowering management in innovative organisations in the 1990s, Management Decision 30(4): 20-43.

http://dx.doi.org/10.1108/00251749210014743 
Rust, R. T.; Chung, T. S. 2006. Marketing models of service and relationships, Marketing Science 25(6): 560-580. http://dx.doi.org/10.1287/mksc.1050.0139

Rust, R. T.; Zeithaml, V. A.; Lemon, K. N. 2000. Driving Customer Equity: How Customer Lifetime Value is Reshaping Corporate Strategy. New York: Free Press.

Saltman, R. B. 1994. Patient choice and patient empowerment in northern European health systems: a conceptual framework, International Journal of Health Services 24: 201-229.

http://dx.doi.org/10.2190/8WMP-RR2K-ABM7-NVNH

Simonson, I. 2005. Determinants of customers' responses to customized offers: conceptual framework and research propositions, Journal of Marketing 69(January): 32-45.

http://dx.doi.org/10.1509/jmkg.69.1.32.55512

Smith, A. K.; Bolton, R. N.; Wagner, J. 1999. A model of customer satisfaction with service encounters involving failure and recovery, Journal of Marketing Research 36(August): 356-372. http://dx.doi.org/10.2307/3152082

Sparks, B. A.; McColl-Kennedy, J. 2001. Justice strategy options for increased customer satisfaction in a services recovery setting, Journal of Business Research 54(3): 209-218.

http://dx.doi.org/10.1016/S0148-2963(00)00120-X

Special Issue on Relationship Marketing. 1995, Journal of the Academy of Marketing Science 23(4).

Spreitzer, G. M. 1995. Psychological empowerment in the workplace: dimensions, measurement, and validation, Academy of Management Journal 38(5): 1442-1465.

http://dx.doi.org/10.2307/256865

Spreng, R. A.; Harrell, G. D.; Mackoy, R. D. 1995. Service recovery: impact on satisfaction and intention, The Journal of Services Marketing 9(1): 15-23.

http://dx.doi.org/10.1108/08876049510079853

Stauss, B. 2002. The dimensions of complaint satisfaction: process and outcome complaint satisfaction versus cold fact and warm act complaint satisfaction, Managing Service Quality 12(3): 173-183. http://dx.doi.org/10.1108/09604520210429240

Tax, S. S.; Brown, S. W. 1998. Recovering and learning from service failure, Sloan Management Review 40(1): 75-88.

Tax, S. S.; Brown, S. W.; Chandrashekaran, M. 1998. Customer evaluations of service complaint experiences: implications for relationship marketing, Journal of Marketing 62(2): 60-76.

http://dx.doi.org/10.2307/1252161

Tressolini, C. P.; The Pew-Fetzer Task Force. 1994. Health Professional Education and Relationship-Centered Care. San Francisco: Pew Health Professions Commission.

Van Looy, B.; Van Dierdonck, R.; Gemmel, P. 1998. Services Management: an Integrated Approach. London: Pitman.

Wall, T. D.; Cordery, J. L.; Clegg, C. W. 2002. Empowerment, performance, and operational uncertainty: a theoretical integration, Applied Psychology: an International Review 51(1): 146-169. http://dx.doi.org/10.1111/1464-0597.00083

Weber, K.; Roehl, W. S. 2001. Service quality issues for convention and visitor bureaus, Journal of Convention and Exhibition Management 3(1): 1-19. http://dx.doi.org/10.1300/J143v03n01_01

West, M. D.; Parent, W. S. 1992. Consumer choice and empowerment in supported employment services: issues and strategies, Journal of the Association for Persons with Severe Handicaps 17(1): 47-52.

Westbrook, R. A.; Oliver, R. L. 1991. The dimensionality of consumption emotion and consumer satisfaction, Journal of Consumer Research 18(June): 84-91. http://dx.doi.org/10.1086/209243 
Wood, R. E.; Bandura, A. 1989. Impact of conceptions of ability on self-regulatory mechanisms and complex decision making, Journal of Personality and Social Psychology 56: 407-415.

http://dx.doi.org/10.1037/0022-3514.56.3.407

Zeelenberg, M.; Pieters, R. 1999. Comparing service delivery to what might have been: behavioral responses to regret and disappointment, Journal of Service Research 2(1): 86-97.

http://dx.doi.org/10.1177/109467059921007

Zeithaml, V. A.; Berry, L. L.; Parasuraman, A. 1988. Communication and control processes in the delivery of service quality, Journal of Marketing 52(April): 35-48.

http://dx.doi.org/10.2307/1251263

Zeithaml, V. A.; Bitner, M. J. 2000. Services Marketing: Integrating Customer Focus Across the Firm. New York: Mcgraw-Hill.

Zimmerman, M. A. 1995. Psychological empowerment: issues and illustrations, American Journal of Community Psychology 23(5): 581-600. http://dx.doi.org/10.1007/BF02506983

Ljudevit PRANIC is an Assistant Professor of Tourism and Hospitality at the University of Split Faculty of Economics. He received his $\mathrm{PhD}$ degree from Temple University in 2008. His primary interests include tourism and hospitality research.

Wesley S. ROEHL is a Professor of Tourism and Hospitality Management at Temple University. He received his $\mathrm{PhD}$ degree from Texas A\&M University in 1988. His primary interests include tourism and hospitality research. 